\title{
Predictions of Galapagos Volcanic Eruption, El Niño, Ecuadorian Earthquake, Global Volcanic Eruption and Forest Fire by Sunspot Number
}

\section{Tai-Jin Kim}

Department of Chemical Engineering, University of Suwon, Hwasung-City, South Korea

Correspondence to: Tai-Jin Kim, tjkim@suwon.ac.kr

Keywords: Prediction, Volcanic Eruption, Ecuadorian Earthquake, Forest Fire, Sunspot Number

Received: August 29, $2019 \quad$ Accepted: January 11, $2020 \quad$ Published: January 14, 2020

Copyright $\odot 2020$ by author(s) and Scientific Research Publishing Inc.

This work is licensed under the Creative Commons Attribution International License (CC BY 4.0).

http://creativecommons.org/licenses/by/4.0/

\section{(c) (i) Open Access}

\section{ABSTRACT}

The earthquake number was correlated $\left(R^{2}=0.8781\right)$ with the volcano number in the East Pacific and Central American countries. The year of volcanic eruptions in the Galapagos Hot Spot (GHS) was proportional to the year of El Niño events $\left(R^{2}=0.9939\right)$ as well as to the year of earthquake events $\left(R^{2}=0.9943\right)$ in Ecuador, Colombia, and Peru from 1977 to 2016. Therefore, there can be El Niño and earthquake events in Ecuador, Colombia and Peru if there are strong volcanic eruptions either from aboveground volcanoes or undersea seamounts in the GHS during the maximal sunspot number's period. Global volcanic eruptions were occurred during the maximal temperature departure, the latter being reversely proportional $\left(R^{2}=0.4512\right)$ to the sunspot number from 1980 to 2019 . Forest fires occurred in middle latitude countries (South Korea, California, western Russia, Australia) around 35 degree from Pacific Equator during La Niña events at the time of the minimal sunspot number. Since there were intense forest fires in South Korea, Australia and California in 2019, more are expected in 2030 due to the 11 year cyclical variation in the sunspot number. The sequence of forest fires can be schematically summarized as below. 1) La Niña event in Equator causes the low vapor pressure of water due to the low sea surface temperature (SST); 2) There is the pumping of freshwater from the warm Pacific Ocean to cold Equator with simultaneous transfer of heat (warm Pacific Ocean to cold Equator) and mass (water enriched Pacific Ocean to water lean Equator); 3) Strong winds from dry zone pass Mountains to cause the forest fires in the residential land with bushes and trees. 4) According to the Bernoulli's principle, the pressure gradient between the high Mountains and the low Ocean, induces the decrease of static velocity gradient for vigorously upwards flares in the Mountains and the residential land during the forest fires, which may be why it is difficult to extinguish the forest fires until burnt up bushes and trees in the Mountains and residential 
land with serious damages. Most effective solution to forest fires is to change the events from La Niña to El Niño for reductions of temperature and pressure gradients by Gay-Lussac's law. Such a transition may be induced by artificial submarine volcanic eruptions among volcanoes of Fernandina, Sierra Negra and Wolf in the GHS for Korea and California. As for Australia, artificial volcanic eruptions can be caused in huge underwater volcano chain in Tasmania. The strong damages of forest fires in South Korea, Australia and California were observed in the period of the minimal sunspot number, as were in October of 2019 to February of 2020. Simultaneous transfers of momentum (velocity), heat (temperature) and mass (freshwater) were occurred from the dry zone or the hot Deserts via the Mountains and the residential land with bushes and trees to the cold Sea or Ocean. It is expected the lowest SST during the year of the minimal sunspot number to induce the strong damages of forest fires, as was in South Korea, Australia and California during the years from 2019 to 2020. $\mathrm{CO}_{2}$ emissions in Australia showed $34.5 \%$ increase, $70 \%$ coal power and no nuclear power to induce bushfires because of increases of ozone hole area and UV radiation for the hot land in the period of La Niña. Fossil fuel operation should be cut down to decrease the ozone hole area and UV radiation for weak bushfires in Australia. A few coming years may still have bushfires in Australia although their damages may not be as terrible as was in 2020. A simple remedy can be the reduction of $\mathrm{CO}_{2}$ emissions as low as possible. It was proposed that the maximal sunspot number induced El Niño event, GHS volcanic eruption and Ecuadorian earthquakes, while the minimal sunspot number induced La Niña events in Ecuador, Colombia, Peru and intense forest fires in middle latitude countries of South Korea (forest fires), Australia (bushfires) and California (wildfires).

\section{INTRODUCTION}

The sunspot numbers between 1870 and 2020 are shown in Figure 1 [1] while the detailed sunspot number between 2000 and 2019 were shown in another work of Hataway [2]. Ultraviolet radiation increases dramatically during high sunspot activity. The converse is true during minimum sunspot activity [3]. Since 1880, El Niño events have occurred roughly every 2 - 7 years with no clear periodicity [4] while the sunspot number (measured in Brussels in Belgium and Ottawa/British Columbia in Canada [5]) changes through an average cycle of 11 years with 14 months standard deviation. The maximal sunspot number causes the highest solar radiation upon the Earth, inducing very strong El Niño events. At the same time, the minimal sunspot number provides the lowest solar radiation upon the Earth inducing strong La Niña events [6] and the forest fires in the middle latitude countries, as illustrated in Figure 1.

Kim [5] proposed the minimal sunspot number strongly $\left(\mathrm{R}^{2}=0.9967\right)$ correlated with the avian influenza virus outbreaks. Kim [7] also showed that there was a close relationship $\left(\mathrm{R}^{2}=0.8539\right)$ between MERS-CoV in Eastern Mediterrane region and maximal sunspot number from 2012 to 2018.

The purpose of the present study is to predict Galapagos volcanic eruptions, Ecuadorian earthquakes, global volcanic eruptions and forest fires using the sunspot number.

\section{BACKGROUND}

\subsection{Oceanic Niño Index}

The Oceanic Niño Index (ONI) [8] in Figure 2 has become the defacto standard that NOAA uses for identifying El Niño (warm) and La Niña (cool) events in the tropical Pacific.

El Niño regions in the Pacific were shown in Figure 3 and defined as [9]: 


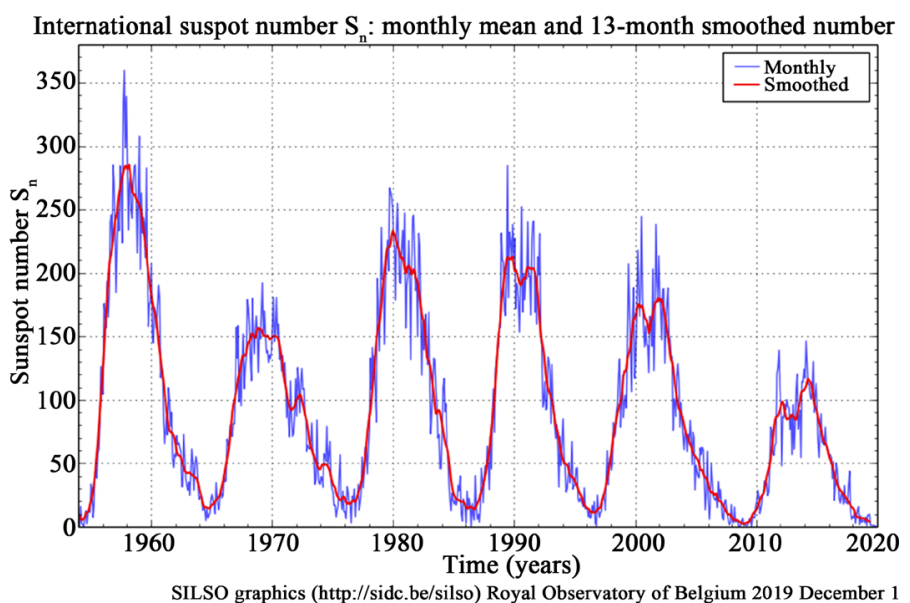

Figure 1. Sunspot numbers with representative years [1] of very strong El Niño events as shown in red, while La Niña events and forest fires in the middle latitude countries are represented in blue with data in [6].

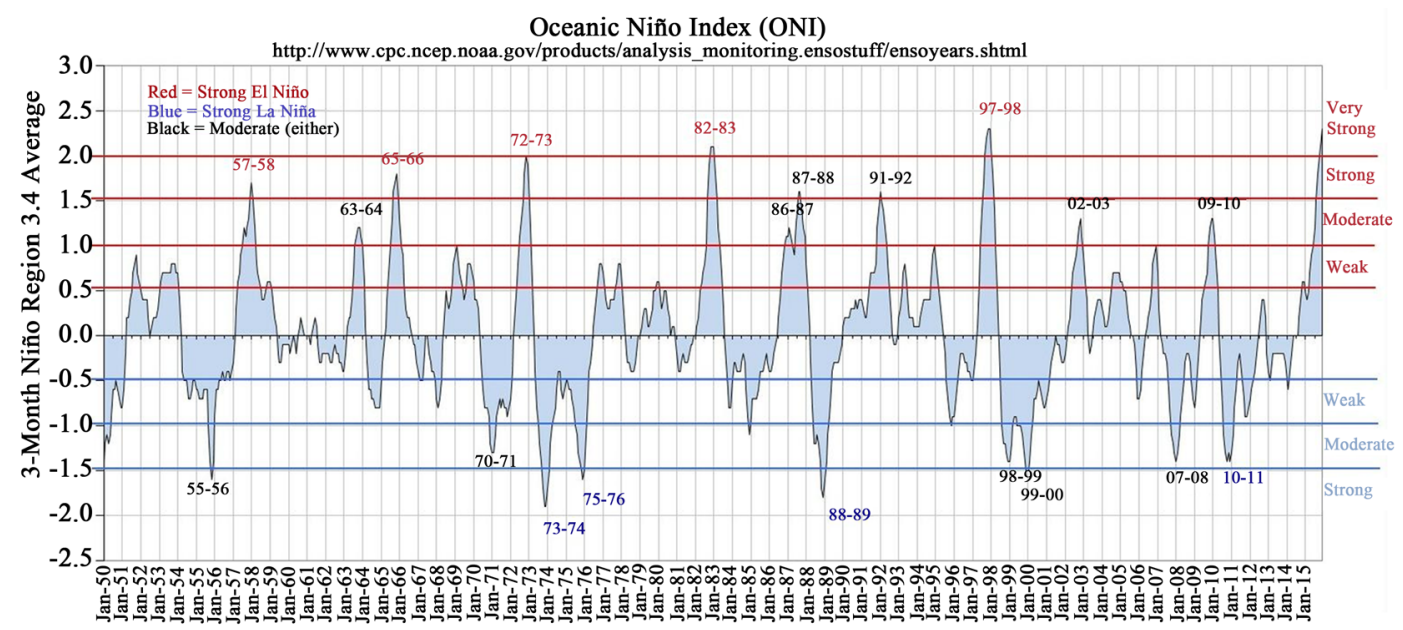

Figure 2. Oceanic Nino Index (ONI) with the running 3-month mean sea surface temperature (SST) anomaly for the Niño 3.4 region [8].

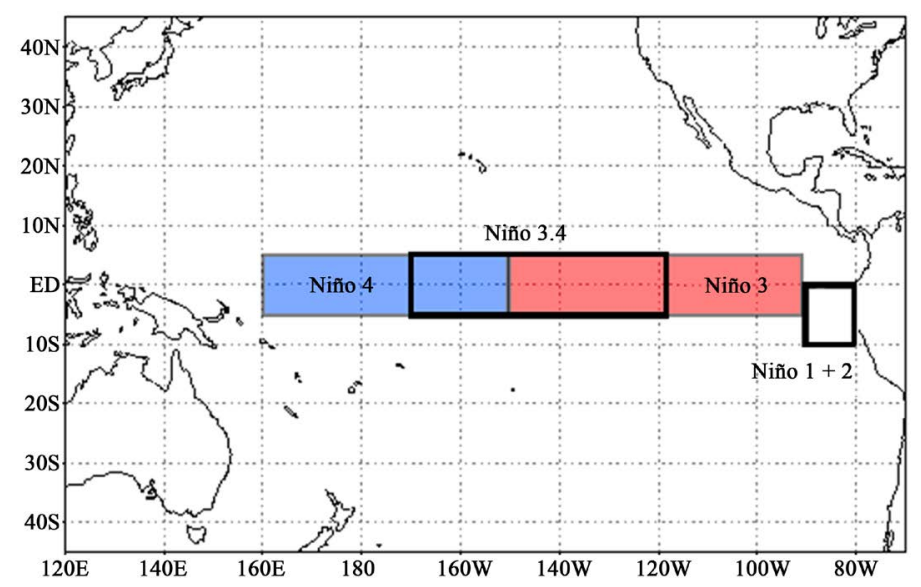

Figure 3. El Niño regions in the Pacific [9]. 
1) El Niño $(1+2) 0^{\circ}-10^{\circ} \mathrm{S}, 80^{\circ}-90^{\circ} \mathrm{W}$ east Pacific.

2) El Niño (3) $5^{\circ} \mathrm{N}-5^{\circ} \mathrm{S}, 90^{\circ}-150^{\circ} \mathrm{W}$ central Pacific.

3) El Niño (4) $5^{\circ} \mathrm{N}-5^{\circ} \mathrm{S}, 150^{\circ}-160^{\circ} \mathrm{W}$ west Pacific.

In Figure 3, El Niño (4) at the western Pacific, showed the strongest relationship with SST anomalies near South Georgia in Antarctica, El Niño (3) at the central Pacific reached an intermediate level. El Niño $(1+2)$ at the eastern Pacific was the weakest level [10]. These different correlations could be caused by the Antarctic Circumpolar Circulation (ACC) flows in the region between New Zealand and Australia (Figure 4) resulting in El Niño (4), El Niño (3), and finally El Niño $(1+2)$. On the other hand, the Peru (Humbolt) Current flows northwards causing El Niño $(1+2)$ in the region of the Galapagos Hot Spot (GHS).

\subsection{Galapagos Hot Spot (GHS)}

The Galapagos Islands are reported to be a "hot spot", which is a region of high thermic flux due to the presence of a magmatic plume ascending from the earth' s mantle $(700-3000 \mathrm{~km})$ [12]. The Galapagos Islands are basaltic rocks produced by volcanic activities caused by magma upwelling $\left(700^{\circ} \mathrm{C}-1300^{\circ} \mathrm{C}\right)$ in the Galapagos Hot Spot (GHS).

During El Niño events, the surface ocean around the Galapagos warms substantially and the islands receive significantly more rainfall than in normal years, as shown in Table 1 . The warmer water is less nutrient-enriched than the cool waters that normally surround the Galapagos and the marine ecosystem consequently becomes disrupted, resulting in a high mortality rate for coral, seabirds, and marine mammals during the strongest El Niño events, such as those in 1982-83 and 1997-98 [13]. The Galapagos ecosystems are supported by a series of Currents that bring cool water into the archipelago. Chief among these is the Humboldt Current, with a width of $900 \mathrm{~km}$ and flow rate of $2 \times 10^{7} \mathrm{~m}^{3} \cdot \mathrm{s}^{-1}$ which comes northwards along the coast of South America. The Current curves toward the left, past the Galapagos Islands, where it moves westerly and constitutes the major portion of the South Equatorial Current, thus completing the counterclockwise circulation of the South Pacific. These cool Currents bring with them nutrient-rich sediment from the ocean floor. This feeds plankton and other tiny animals which form the base of the food chain.

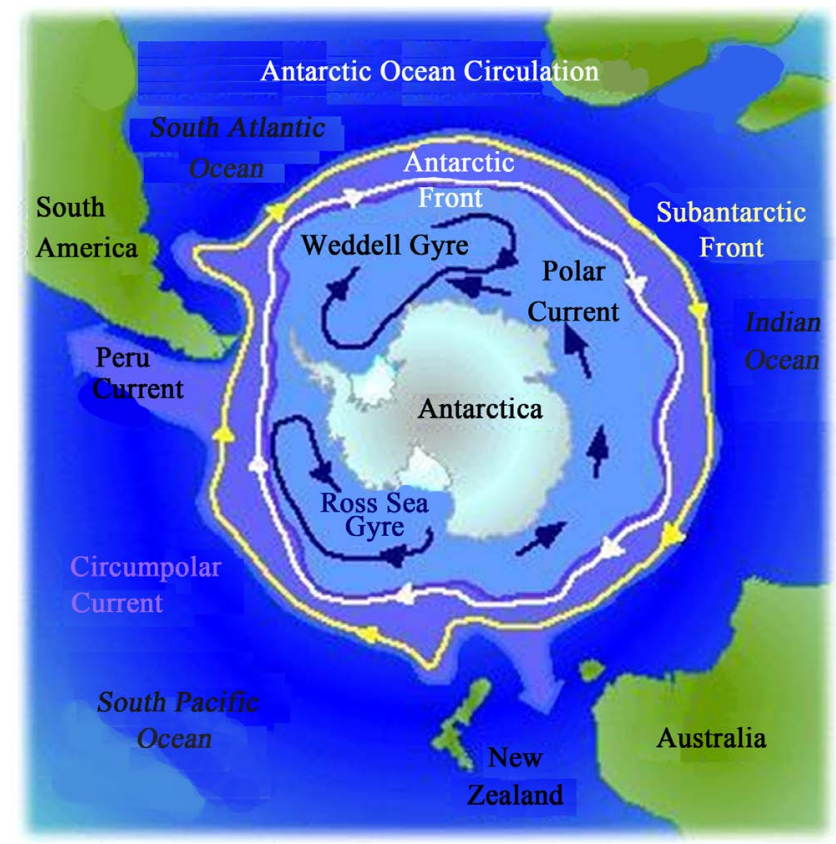

Figure 4. Antarctic Circumpolar Circulation (ACC) flows through one centrifugal exit between New Zealand and Australia while the Peru Current travels through another centrifugal exit along the west coast of South America [11]. 
Table 1. East Pacific and Central American countries stating precipitation, area, heat amount, volcano, earthquake and Ridge [6].

\begin{tabular}{|c|c|c|c|c|c|c|c|c|}
\hline \multirow[b]{2}{*}{ Country } & \multicolumn{2}{|c|}{ Precipitation } & \multirow[b]{2}{*}{$\begin{array}{l}\text { Area } \\
\left(\mathrm{km}^{2}\right)\end{array}$} & \multicolumn{2}{|c|}{ Heat Amount } & \multirow[b]{2}{*}{$\begin{array}{l}\text { Volcano } \\
\text { Number }\end{array}$} & \multirow[b]{2}{*}{$\begin{array}{c}\text { Earthquake } \\
\text { Number }\end{array}$} & \multirow[b]{2}{*}{ Ridge } \\
\hline & $\begin{array}{l}\text { During } \\
\text { year of } \\
2011 \\
(\mathrm{~mm})\end{array}$ & Rank & & $\times 10^{18} \mathrm{cal}$ & Rank & & & \\
\hline Costa Rica & 2926 & 1 & 51,100 & 2.3 & 10 & 13 & 11 & $\begin{array}{l}\text { Cocos (Costa Rica } \\
\text { Province, Cocos } \\
\text { Island Province, } \\
\text { Southwest Province) }\end{array}$ \\
\hline Panama & 2692 & 2 & 74,177 & 3.0 & 9 & 3 & 4 & Coiba \\
\hline Colombia & 2612 & 3 & $1,141,748$ & 45 & 1 & 16 & 25 & $\begin{array}{c}\text { Carnegie/Malpelo/ } \\
\text { Columbia-Ecuador } \\
\text { Trench }\end{array}$ \\
\hline Nicaragua & 2391 & 4 & 129,494 & 4.7 & 6 & 19 & 9 & Nicaraguan fore-arc \\
\hline Ecuador & 2087 & 5 & 283,561 & 8.7 & 5 & 43 & 24 & Carnegie \\
\hline Guatemala & 1996 & 6 & 108,889 & 3.3 & 7 & 29 & 25 & $\begin{array}{c}\text { Middle } \\
\text { American Trench }\end{array}$ \\
\hline Honduras & 1976 & 7 & 112,492 & 3.3 & 8 & 4 & 3 & $\begin{array}{c}\text { Middle } \\
\text { American Trench }\end{array}$ \\
\hline Peru & 1738 & 8 & $1,279,999$ & 35 & 2 & 29 & 56 & Nazca \\
\hline El Salvador & 1724 & 9 & 21,040 & 0.5 & 11 & 22 & 16 & $\begin{array}{c}\text { Middle } \\
\text { American Trench }\end{array}$ \\
\hline Chile & 1522 & 10 & 756,102 & 18 & 4 & 137 & 133 & Chile Rise \\
\hline
\end{tabular}

\section{RESULTS}

\subsection{Volcanic Seamounts}

The planet's crust is broken into 17 major rigid tectonic plates while volcanoes and earthquakes are generally found in the plate boundaries at the bottom of the oceans. Therefore, most volcanic activity is submarine, as seen in deep sea hydrothermal $\left(\geq 350^{\circ} \mathrm{C}\right)$ black smoker's vents releasing volcanic gases at the East Pacific Rise [14].

Volcanic gases are commonly composed in the order of $\mathrm{H}_{2} \mathrm{O}(37 \%-97.1 \%), \mathrm{CO}_{2}, \mathrm{SO}_{2}(0.50 \%$ $11.8 \%), \mathrm{H}_{2}, \mathrm{CO}, \mathrm{H}_{2} \mathrm{~S}(0.04 \%-0.68 \%), \mathrm{HCl}, \mathrm{HF}$ [15]. Toxic chemicals $\left(\mathrm{SO}_{2}, \mathrm{H}_{2} \mathrm{~S}, \mathrm{HCl}, \mathrm{HF}_{2} \mathrm{H}_{2} \mathrm{SO}_{4}\right)$ from submarine volcanoes have reduced the fishery productivity [6].

Table 1 summarizes the East Pacific and Central American Countries stating precipitation, area, heat source, volcano, earthquake, and Ridge.

In Figure 5, the earthquake number $(\mathrm{x})$ in Table 1 was correlated with the volcano number $(\mathrm{y})$ as $y=$ $0.904 x+2.032$ with a significant correlation coefficient $\left(\mathrm{R}^{2}=0.8781\right)$. Therefore, it can be expected that 


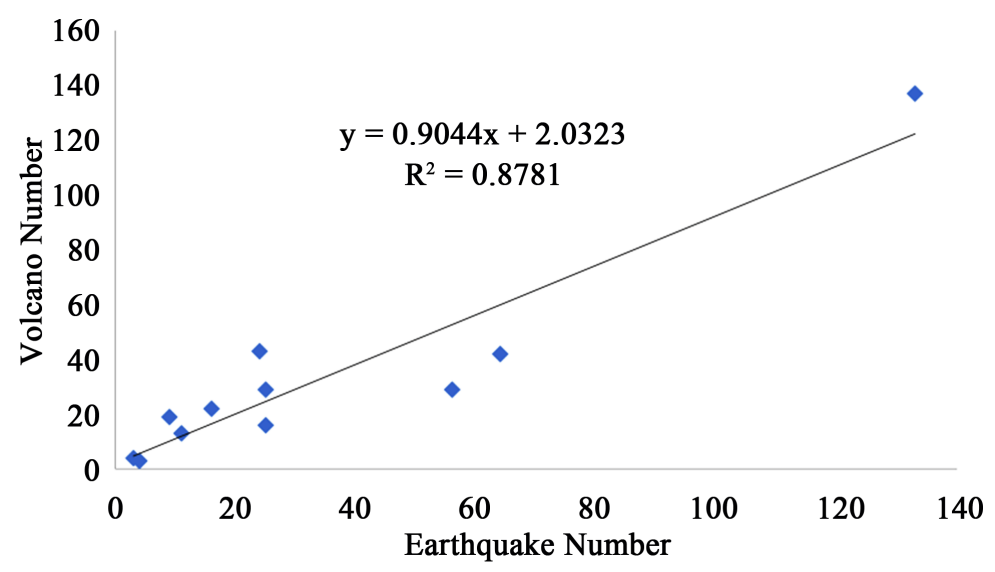

Figure 5. Correlation of earthquake number with volcano number in the East Pacific and Central America.

the earthquake number is linearly proportional to the volcano number in the East Pacific and Central American countries.

\subsection{Mechanism of El Niño-Southern Oscillation (ENSO)}

The mechanism of ENSO has not been resolved yet. Kim [6] revealed that El Niño can be caused by strong solar radiation during the year of the maximal sunspot number. On the other hand, La Niña may be caused by weak solar radiation during the year of the minimal sunspot number, as illustrated in Figure 1 .

The warm SST induced by the volcanic activity in either Antarctica or South America, moves to the east Pacific via the Peru Current or to the west Pacific via the East Australian Current [6]. Since the volcanic activity in the GHS can impact the warm SST from the GHS (east Pacific) to the west Pacific, the major controlling parameter to determine the current direction of the Central Pacific Current (CPC) is the degree of the volcanic activity in the GHS.

Since the sunspot number in Figure 1 varies periodically every 11 years with a standard deviation of 14 months, its average is about $6\left\{\left(=11+\frac{14}{12}\right) / 2\right\}$ years, which could be the reason why El Niño events occur every 2 to 7 years. There can be four typical cases such as strong El Niño, weak El Niño, strong La Niña and weak La Niñafor the maximal, two intermediates and the minimal sunspot numbers with approximate duration of 3 years in each case [6]. There were two peaks in both volcanic eruptions and earthquakes in the GHS, Ecuador, Colombia, and Peru [16]. Such a two peak pattern is similar to the solar insolation [17] for the latitude $0^{\circ}$ March Equinox and September Equinox while the latitude of the Galapagos Islands is $-0.777^{\circ}$. Therefore, maximal sunspot number, with the strong solar insolation in the GHS, governs the volcanic eruptions in the GHS with relationship in earthquakes in Ecuador, Colombia and Peru [16].

Since the December Solstice in the Northern Hemisphere is equivalent to the June Solstice in the Southern Ocean, there can be the strong solar radiation during December to induce the Antarctic volcanic evolutions in the Rises and Ridges in Antarctica [6]. This can be one of the reasons why El Niño events have been commonly noticed during early December. There are two cases of El Niño events [6]. One is the strong El Niño with strong volcanic eruptions in the seamounts of Antarctica, and Central, and South America while another is the weak El Niño with weak volcanic eruptions in such areas. As for the La Niña event, the analogy is the same except without strong volcanic eruptions for two La Niña events [6].

\subsection{Volcanic Eruptions in GHS and Earthquakes in Ecuador, Colombia, and Peru}

The low correlation coefficient $\left(\mathrm{R}^{2}=0.1631\right)$ between the year of volcanic eruption in the GHS and 
the maximal sunspot number in Figure 6 could be caused by data only from observable aboveground volcanic eruptions [16] without invisible undersea volcanic eruptions from 70 unknown seamounts in the GHS [18]. The year of volcanic eruptions in the Galapagos Hot Spot (GHS) was proportional to the year of the El Niño events $\left(\mathrm{R}^{2}=0.9939\right)[6]$.

The year of volcanic eruptions in the GHS showed significant $\left(\mathrm{R}^{2}=0.9943\right)$ linearity with the year of earthquake events [16], as shown in Figure 7. It is necessary to prepare for volcanic eruptions in the GHS, El Niño events and earthquakes in Ecuador, Colombia, and Peru during the period of the maximal sunspot number.

\subsection{Global Volcanic Eruptions with Maximal Temperature Departure}

The Earth is covered with oceans and lands and absorbs 89PW (51\%) from incoming solar radiation (174 PW), which may be delivered to magma in the global volcanoes, the energy of which can be expressed as volcanic eruptions during the maximal temperature departure. Sunspot number enhances ultraviolet (UV) radiation on the Earth for increases of geothermal energy and ultimately volcanic eruptions.

Since 1979, NOAA satellites measured the latest global average tropospheric temperatures during 1980 to 2019 [19], as shown in Figure 8.

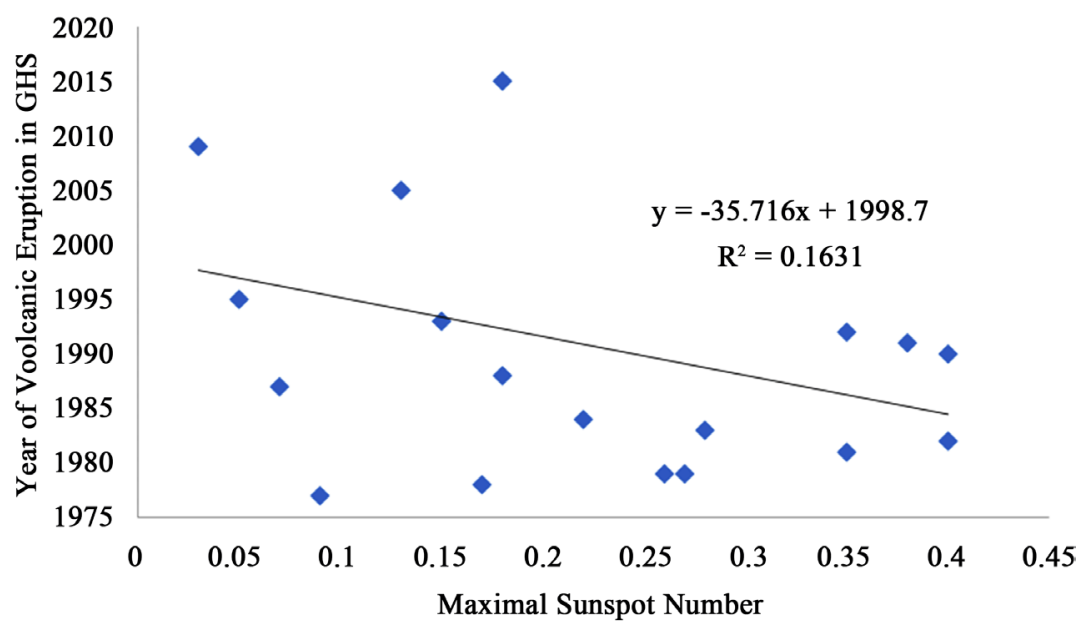

Figure 6. Year of volcanic eruption in the GHS [16] versus the maximal sunspot number in Figure 1.

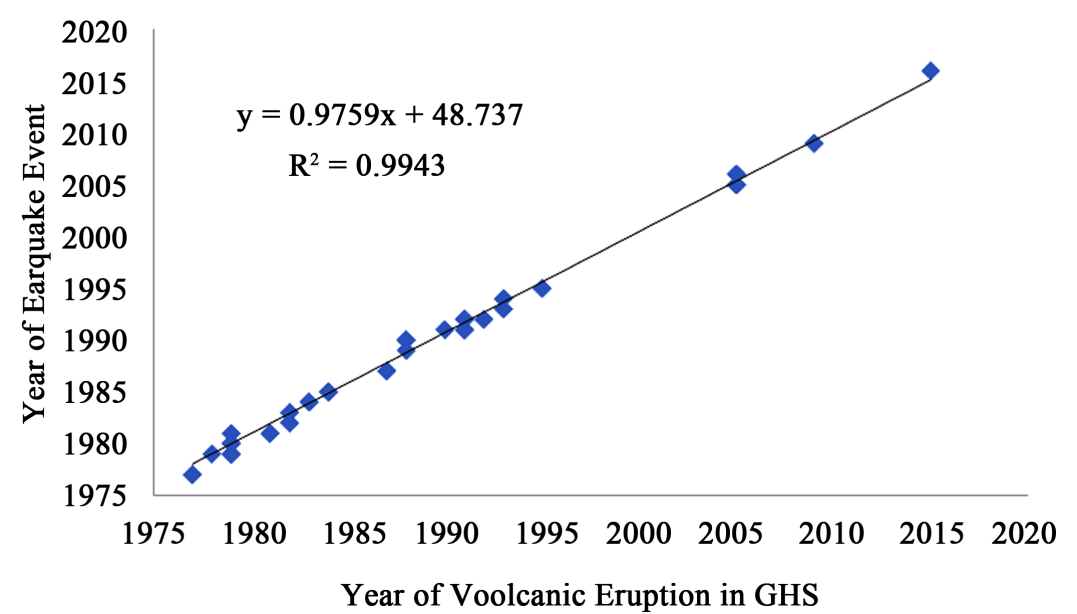

Figure 7. Year of volcanic eruption in the GHS versus the year of earthquake event in Ecuador, Colombia and Peru from 1977 to 2016, with data in [16]. 


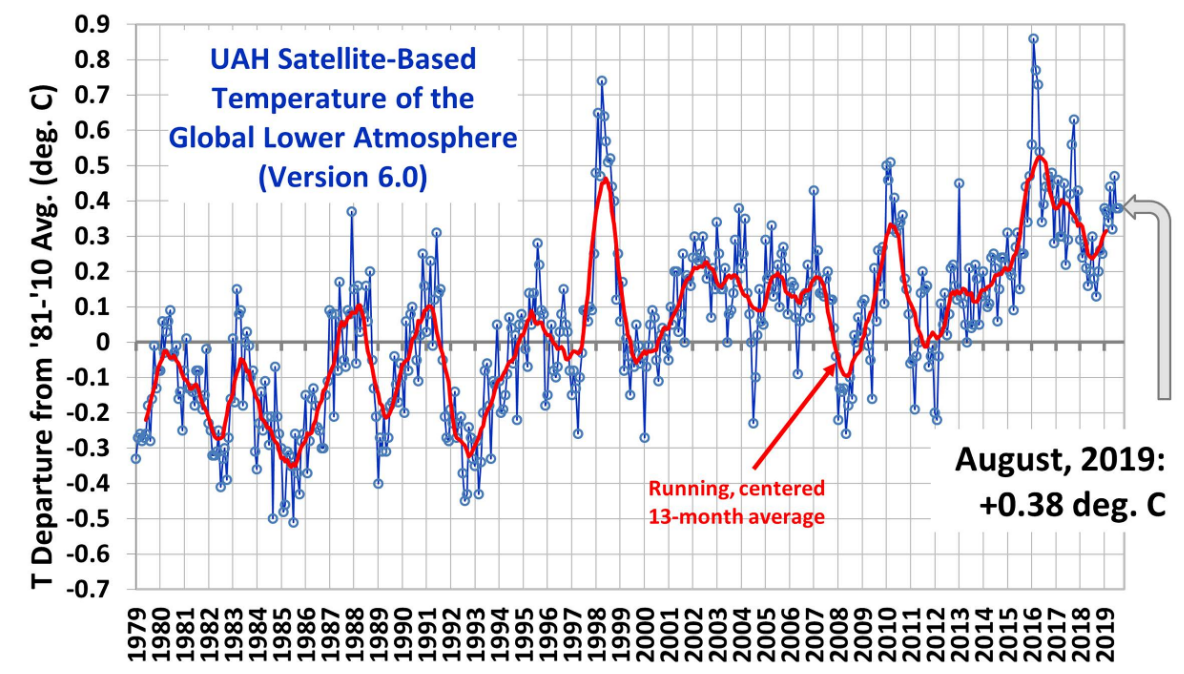

Figure 8. The UAH satellite-based temperature departure with the peak of yearly data from 1980 to 2019 associated with global volcanic eruptions in Table 2 [20].

Energy flow is expressed by temperature. When maximal temperature is reached, there are volcanic eruptions around the world. It is therefore important to predict the volcanic eruption in advance by satellite-based temperature profile. Since the maximal temperature departure was the highest in 2016 and 2017, there were many volcanic eruptions around the world, as shown in Table 2.

Global volcanic eruptions in Table 2 were occurred during the maximal temperature departure with the peak of yearly data, the latter being proportional $\left(\mathrm{R}^{2}=0.4512\right)$ to the sunspot number from 1980 to 2019, as shown in Figure 9.

It is thus proposed that the maximal temperature departure causing the global volcanic eruptions was reversely proportional $\left(\mathrm{R}^{2}=0.4512\right)$ to the sunspot number from 1980 to 2019 . It was known that the minimum sunspot number induced La Niña in 12 years of 1983, 1988, 1996, 1998, 2000, 2005, 2006, 2007, 2016, 2017, 2018, 2019 [6].

The present study revealed that there were frequent volcanic eruptions in the periods of La Niña, during which the minimum sunspot number associated with the maximal temperature departure could be frequently expected.

\subsection{Forest Fire}

Forest fires called wildfires in California and bushfires in Australia are natural events induced by El Niño in Indonesia at the Pacific Equator. On the other hand, there were intensive forest fires in the region of the middle latitude countries; South Korea (1965, 1970, 1974-1976, 1978, 1985, 1987-1988, 1995, 1996, 1997, 2000, 2005, 2009, 2019), California (2007, 2008, 2009, 2017, 2019), Malibu (2007), Victoria, New South Wales, Queensland of Australia (2009, 2019, 2020), and western Russia (2010), as reviewed partly by Lee [22]. It is interesting to note that these years with intense forest fires correspond to years of La Niña events in Figure 1 [6], located in the middle latitude of about 35 degree such as South Korea $\left(33^{\circ} \mathrm{N}\right.$ $\left.38^{\circ} \mathrm{N}\right)$, California $\left(32^{\circ} \mathrm{N}-42^{\circ} \mathrm{N}\right)$ ), and western Russia $\left(45^{\circ} \mathrm{N}-55^{\circ} \mathrm{N}\right)$ while Victoria $\left(37^{\circ} \mathrm{S}\right)$, New South Wales $\left(32^{\circ} \mathrm{S}\right)$ and Queensland $\left(23^{\circ} \mathrm{S}\right)$ of Australia from Pacific Equator. Such countries are centered at latitudes between Equator $\left(0^{\circ}\right)$ and Arctic Circle $\left(66.5^{\circ} \mathrm{N}\right) /$ Antarctic Circle $\left(66.5^{\circ} \mathrm{S}\right)\left(66.5^{\circ}\right.$ divided by 2 for average is equal to $33^{\circ}$, approximately eqivalent to the latitudes of such countries.) The effect of pumping the freshwater in such locations can be thus directed toward either Arctic Circle/Antarctic Circle or Equator. SinceLa Niña occurs at the Equator, the outbreak of forest fires at residential land with bushes, forest and trees can be occurred during the event of La Niña at the Equator. It appears that cold water in the Pacific Equator during La Niña event may pump the freshwater from middle latitude countries with warm 
Table 2. Global volcanic eruptions with maximal temperature deparures (1980-2019).

\begin{tabular}{|c|c|c|}
\hline Year & Maximal Temperature Departure [19] & Volcanic Eruption (Country) [21] \\
\hline \multirow[t]{2}{*}{1980} & -0.03 & Mount St. Helens (USA), Erebus (Antarctica) \\
\hline & & Erebus (Antarctica) \\
\hline 1983 & -0.06 & Mount Kilauea (Hawaii) \\
\hline 1988 & 0.11 & Fernandina (Galapagos) \\
\hline 1991 & 0.11 & Pinatubo (Philippines) \\
\hline 1996 & 0.09 & Mount Monteserrat (United Kingdom) \\
\hline 1998 & 0.47 & Piton de la Fournaise (Indian Ocean) \\
\hline 2002 & 0.20 & Nyiragongo (Congo) \\
\hline 2005 & 0.20 & Santa Ana (El Salvador) \\
\hline 2006 & 0.11 & Auqustine, Alaska \\
\hline 2007 & 0.18 & Kelut, Indonesia \\
\hline \multirow[t]{7}{*}{2013} & 0.46 & Mountain Etna (Italy), Mount Pavlof (Alaska), \\
\hline & & Mount Sinabung (Indonesia), \\
\hline & & Copahue (Argentina), Nishinoshima (Japan), \\
\hline & & Mount Sakurajima (Japan), \\
\hline & & Tungurahua (Ecuador), Mount Lokon (Indonesia) \\
\hline & & Mount Karangetang (Indonesia), \\
\hline & & Kilauea (Hawaii), Popocatepeti (Mexico) \\
\hline \multirow[t]{8}{*}{2015} & 0.25 & Mount Etna (Italy), Wolf (Galapagos), \\
\hline & & Cotopaxi (Ecuador), Villarrica (Chile), \\
\hline & & Hunga Tonga (Tonga), \\
\hline & & Mount Sinabung (Indonesia), \\
\hline & & Piton de la Fournaise (Reunion Island), \\
\hline & & Kilauea (Hawaii), Momotombo \\
\hline & & (Nigaragua), Colima (Mexico), \\
\hline & & Calbuco (Chile) \\
\hline \multirow[t]{4}{*}{2016} & 0.53 & Tungurahua (Ecuador), Villarrica (Chile), \\
\hline & & Mount Sinabung (Indonesia), \\
\hline & & Piton de la Fournaise (Reunion Island), \\
\hline & & Kilauea (Hawaii), Mount Pavlof (Alaska), \\
\hline
\end{tabular}




\section{Continued}

\begin{tabular}{ll}
\hline & Mount Bromo (Indonesia), Nyiragongo (Congo) \\
& Erta Ale (Ethiopia) \\
& Shiveluch (Russia), Villarrica (Chile), \\
& Mount Sinabung and Mount Agung (Indonesia), \\
& Turriaiba (Costa Rica), \\
& Piton de la Fournaise (Reunion Island), \\
& Kilauea (Hawaii), Bogoslof (Alaska), \\
& ManaroVoui (Vanuatu), Mount Etna (Italy) \\
& Kadovar (Papua New Guinea), \\
& Mayon (Philippines), Nyamuragira (Congo) \\
& Kerinci (Indonesia), Merapi (Indonesia) \\
& Krakatau (Indonesia), BarrenIsland (India), \\
& Karanggetang (Indonesia), \\
& Tinakula (Solomon Island) \\
& Poas (Costa Rica), Karymsky(Russia), \\
& Sangay (Ecuador), Asosan (Japan), \\
& Ubinas (Peru), Shishaldin (United States), \\
& Tangkubanparahu (Indonesia) \\
&
\end{tabular}

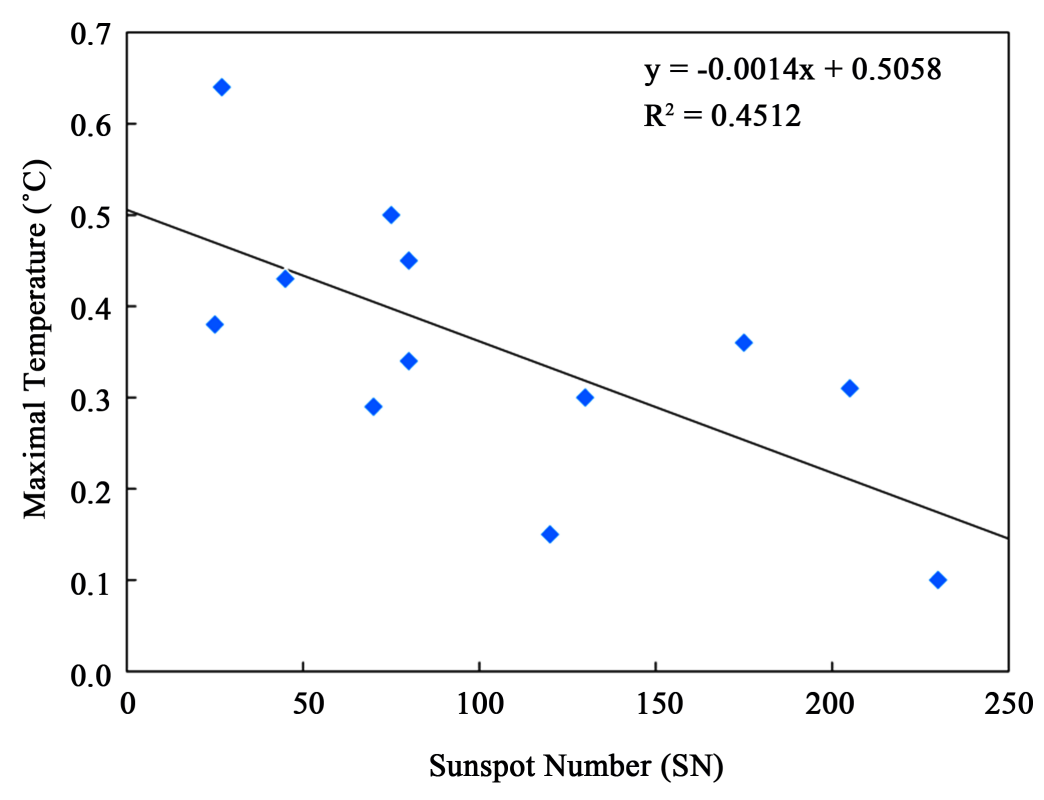

Figure 9. Global volcanic eruptions in Table 2 were occurred during the maximal temperature departure with the peak of yearly data, linear $\left(R^{2}=0.4512\right)$ to the sunspot number from 1980 to 2019 . 
and high water vapor pressure to the Pacific Equator, having cold and low water vapor pressure causing a lack of moisture. Since there were intense forest fires during the minimal sunspot number in 1965, 1976, 1986, 1995-1999, 2007-2010, 2017, 2018-2019 in Korea, Australia and California, more big forest fires are expected in 2030 when the minimal sunspot number or the strong La Niña are reached due to the 11 years cycle. For example, wildfires in California near Los Angeles can be diminished if artificial reservoirs, lakes, ponds and rivers are built and filled with freshwater to keep the air humidity in a wet state. During August with hottest temperature $\left(84.5^{\circ} \mathrm{F}\right)$ and lowest rainfall $(0.4$ average rainfall days), there is a negligible rainfall in California with the greatest potential for wildfires in October, as evidenced by wildfires in Los Angeles in California at October 7, 2017 and October 24, 2019. The recent approach to shut down the electrical power is not the appropriate method for preventing the wildfires in California or elsewhere. Electrical cables passing over the Sierra Nevada Mountains and residential land carried by winds, can be buried into the underground so that electrical sparks from broken cables, could not ignite wildfires originating at the aboveground bushes and trees in the Mountains and residential land.

Many sprayers may be installed in reservoirs, rivers, lakes and ponds around the Mountains and the residential land so that water droplets are fully sprayed over the bushes and trees to be well moisturized and blanketed from the ignition of wildfires. Such foggy environments may inhibit and reduce the potentials of wildfires in the Mountains and the residential land.

According to Gay-Lussac's law [23], the pressure of a given mass of air varies directly with the absolute temperature of the air. Therefore, the river heading to the Pacific Ocean along the western side of the Sierra Nevada or a big reservoir near Los Angeles filled with desalinated freshwater from the Pacific Ocean for partial moisture conditions in California. Such artificial freshwater systems pass central California weakening the Winds of Diablo and Santa Ana by latent and vaporization heats of freshwater for humid air and minimizing the potential for wildfires. Furthermore, the direction of rivers in California should be changed to flow toward the Pacific Ocean with the cold California Current so that there is less pressure difference between the hot Sierra Nevada and the cold Pacific Ocean inducing weak winds. To decrease wildfires in California, rivers should be built along the San Joaquin Valley resulting in moist air while winds blow from the Mojave Desert at higher pressure, passing over the Sierra Nevada Mountains and residential land toward the Pacific Ocean at low pressure. We cannot avoid the wildfires in Korea, Australia and California during La Niña events because of dry and hot winds passing though Deserts and Mountains with bushes and trees to reaching the residential land and the cold Sea or Ocean, whose freshwater is pumped out to the Equator during La Niña events with cold SST creating strong winds. The area of the dry Mojave Desert in California can be diminished by planting in the long term for the cold and moist air.

As for Australia, it is necessary to alert the bushfires since the duration of December to February is the strong period of La Niña event with cold SST. In fact, the temperature of the Simson Desert was extremly hot $\left(50^{\circ} \mathrm{C}\right)$ and dry. Western suburbs of Sydney was recorded at Penrith with $48.9^{\circ} \mathrm{C}$ on 4 January 2020 . According to Gay-Lussac's law [23], the enhanced temperature gradient causes the increased pressure gradient for strong winds from the high pressure place of the Simson Desert $\left(50^{\circ} \mathrm{C}\right)$, the Mountains and the residential land (Penrith $48.9^{\circ} \mathrm{C}$, Sydney $26^{\circ} \mathrm{C}$ ) to the low pressure place of the cold Ocean $\left(17^{\circ} \mathrm{C} /\right.$ the Sea).

The years of the minimal sunspot number was significantly proportional $\left(R^{2}=0.9995\right)$ to the years of the record low temperature in Chicago [6]. It is therefore expected the lowest SST during the year of the minimal sunspot number to induce the strong damages of forest fires, as was in South Korea, Australia and California during the years from 2019 to 2020. Since the cyclical sunspot number is 11 years with 14 months standard deviation [2], next major forest fires are expected in the years of 2030 and 2031.

$\mathrm{CO}_{2}$ emissions are annually increased. Consequently, the ozone hole area is also increased with the increase of UV radiation. Enhanced UV radiation induces the hot land, leading to the increased temperature gradient between the hot land and the cold Ocean in the period of La Niña event. Such an intense temperature gradient causes the strong wind for the bushfires with severe damages, as was in January of 2020 in Victoria, New South Wales and Queensland. $\mathrm{CO}_{2}$ emissions in Australia are 415 million ton in 2016 and 558 million ton in 2018 with $34.5 \%$ increase. Australia has $70 \%$ coal power for electricity without nuclear power. It is necessary to cut down coal power and build new nuclear powers for decreases of $\mathrm{CO}_{2}$ emissions, ozone hole area, UV radiation and hot lands. Such an action may decrease the gradients of tem- 
perature and pressure for partial prevention of bushfires. Besides, the UV radiation and the ozone hole area is relatively large in Australia due to its close location to the Antarctic. Since the years of 2019 and 2020 were the minimum sunspot number, there were tragic bushfires in all around of Australia, as shown in the photo of satellites. A few coming years may still have bushfires in Australia although their damages may not be so terrible as was in 2020. A simple remedy can be a decrease of $\mathrm{CO}_{2}$ emissions as low as possible.

The sequence of forest fires can be schematically summarized as below.

1) La Niña event in Equator causes the low vapor pressure of water due to the low SST,

2) There is the pumping of freshwater from the warm Pacific Ocean to the cold Equator with simultaneous transfer of heat (warm Pacific Ocean to cold Equator) and mass (water enriched Pacific Ocean to water lean Equator),

3) Strong winds from a hot and dry zone or Deserts pass the Mountains to cause the forest fires in the Mountains and the residential land with bushes and trees.

4) According to Bernoulli's principle [24], the pressure gradient between the high Mountains and the low Ocean, induces the decrease of static velocity gradient for vigorously upwards flares in the Mountains and the residential land during the forest fires, which may be why it is difficult to extinguish the forest fires until burnt up bushes and trees in the Mountains and the residential land with serious damages.

The summary of forest fires are shown in Table 3.

Hot, dry and strong winds blow from the hot and dry zone or Deserts passing over Mountains and residential land toward the cold and wet Sea or Ocean. This induces the temperature gradient between the hot Desert and cold Ocean, causing the pressure gradient for strong winds at downside residential land that have bushes and trees where forest fires originate.

Table 3. Summary of major forest fires.

\begin{tabular}{|c|c|c|c|c|c|c|}
\hline Country & $\begin{array}{l}\text { Dry Zone/ } \\
\text { Hot Desert }\end{array}$ & Season & Current & Mountains & $\begin{array}{l}\text { Residential } \\
\text { Land }\end{array}$ & $\begin{array}{l}\text { Cold } \\
\text { Sea }\end{array}$ \\
\hline Korea & $\begin{array}{c}\text { Chuncheon, } \\
\text { Wonju }\end{array}$ & $\begin{array}{l}\text { Spring, } \\
\text { Fall }\end{array}$ & $\begin{array}{c}\text { North Korean } \\
\text { Cold Current } \\
{[25]}\end{array}$ & $\begin{array}{c}\text { Taebaeck } \\
\text { Mountains } \\
(\text { Elevation }>1000 \mathrm{~m}) \\
(\text { Length } 500 \mathrm{~km})\end{array}$ & $\begin{array}{c}\text { Sokcho, } \\
\text { Gangneong }\end{array}$ & East Sea \\
\hline Australia & $\begin{array}{l}\text { Simpson, } \\
\text { Strzelecki, } \\
\text { Tirari, } \\
\text { Sturt Stony }\end{array}$ & $\begin{array}{c}\text { Fall, } \\
\text { Winter }\end{array}$ & $\begin{array}{c}\text { East } \\
\text { Australian } \\
\text { Current [26] }\end{array}$ & $\begin{array}{l}\text { The Blue } \\
\text { Mountains } \\
\text { (Elevation; } \\
1189 \mathrm{~m}, \\
\text { Length } 96 \mathrm{~km} \text { ), } \\
\text { Great Dividing } \\
\text { Range }\end{array}$ & $\begin{array}{c}\text { New South } \\
\text { Wales } \\
\text { (Sydney), } \\
\text { Victoria } \\
\text { (Melbourne), } \\
\text { Queensland } \\
\text { (Brisbane) }\end{array}$ & $\begin{array}{l}\text { Tasman } \\
\text { Sea, } \\
\text { Pacific } \\
\text { Ocean, } \\
\text { Coral Sea }\end{array}$ \\
\hline California & $\begin{array}{c}\text { Mojave, Sierra } \\
\text { Nevada, } \\
\text { Colorado, } \\
\text { Great Basin }\end{array}$ & $\begin{array}{c}\text { Fall, } \\
\text { Winter }\end{array}$ & $\begin{array}{c}\text { California } \\
\text { Current, } \\
\text { Southern } \\
\text { California } \\
\text { Countercurrent, } \\
\text { Davidson } \\
\text { Current [27] }\end{array}$ & $\begin{array}{c}\text { Tehachapi, San } \\
\text { Gabriel, San } \\
\text { Bernardino, } \\
\text { Sierra Nevada } \\
\text { Valley } \\
(300-4300 \mathrm{~m}) \\
\text { San Joaquin } \\
\text { Valley }(111 \mathrm{~m})\end{array}$ & $\begin{array}{l}\text { San } \\
\text { Francisco, } \\
\text { Los } \\
\text { Angeles }\end{array}$ & $\begin{array}{l}\text { Pacific } \\
\text { Ocean }\end{array}$ \\
\hline
\end{tabular}


The solution to the wildfires can be firstly decreasing the pressure difference by either cooling the Desert or warming the Sea. Cooling the Desert is beyond consideration, but warming the Sea can be achieved if artificial El Niño is made. It is thus necessary to change the events from La Niña to El Niño. Such a transition may be induced by artificial submarine volcanic eruptions among volcanoes of Fernandina, Sierra Negra and Wolf in the Galapagos Hot Spot, whose volcanic eruptions caused El Niño [16], for Korea and California located in the Northern Hemisphere. As for Australia in the Southern Hemisphere, there are giant undersea volcano chain discovered off the coast of Tasmania [28] to be used as the source of warm seawater by artificial volcanic eruption for the event of El Niño.

In view of local points, there are two salty lakes in eastern Korea; Lake Cheongcho (Mountain Seollak, Chuncheon City-Dry Zone, Sokcho City-Land, East Sea-Cold Sea), Lake Gyeongpo (Mountain Ohdae, Wonju City-Dry Zone, Gangneong City-Land, East Sea-Cold Sea). Since such lakes are connected to the cold East Sea in their inlets, it is necessary to close their small entryways not to take the cold seawaters of the East Sea for reductions of the temperature gradient and forest fires.

As for Australia, there are three major states of bushfires in Victoria, New South Wales and Queensland. There are many lagoons, inlets, lakes and bays in contact with cold seawaters in South Pacific Ocean, Coral Sea and Tasman Sea, starting from Antarctica to the East Australian Current [6]. Since Sydney used to have frequent bushfires, it is necessary to build artificial gateways near Sydney, such as in Congwoy Bay and Watsons Bay. Such Bay should be closed not to be in contact with the cold seawaters, especially in the periods of La Niña events.

As for San Francisco of California, San Francisco Bay can be temporally blocked not to be in contact with the cold California Current, especially in the periods of La Niña events. There are Santa Barbara Channel flowing through Los Angeles. Three major islands such as Santa Catalina, Santa Nicolas and Santa Clemerte, whose stations of solar energy and current energy may increase the sea surface temperature of the seawater in front of Los Angeles for reductions of the temperature gradient and forest fires.

According to Gay-Lussac's law [23] in physical chemistry, the temperature gradient induces the pressure gradient with winds. Bernoulli's principle [24] in fluid dynamics states that an increase in the speed of a fluid occurs simultaneously with a decrease in static pressure. Therefore, the forest fires induced by pressure difference between the hot and dry Desert through the Mountains and the cold Ocean, are vigorously activated to flare upwards. This is why it is very difficult to control the forest fires unless there is warm Sea or Ocean, instead of cold ones, for lower pressure gradient, reduced velocity gradient and flares.

Kim [6] suggested that there was strong correlation between El Niño events with volcanic eruptions in the GHS. Therefore, La Niña events can be switched to El Niño if there is a volcanic eruption in the GHS. The driving force of moisture from the Pacific Ocean or the Sea to the Equator can possibly be decreased to lower potentials of forest fires in Korea, Australia and California so long as strong La Niña is changed to weak El Niño.

Such a transition may be induced by artificial submarine volcanic eruptions among volcanoes of Fernandina, Sierra Negra and Wolf in the GHS for Korea and California in the Northern Hemisphere while by the underwater volcano chain in Tasmania for Australia in the Southern Hemisphere.

\section{CONCLUSIONS}

The year of volcanic eruptions in the Galapagos Hot Spot (GHS) was proportional to the year of the El Niño events $\left(R^{2}=0.9939\right)$ as well as to the year of earthquake events $\left(R^{2}=0.9943\right)$ in Ecuador, Colombia, and Peru from 1977 to 2016. Therefore, there can be El Niño and earthquake events in Ecuador, Colombia and Peru if there are strong volcanic eruptions either from aboveground volcanoes or undersea seamounts in the GHS during the maximal sunspot number.

Global volcanic eruptions occurred during the maximal temperature departure, the latter being proportional $\left(R^{2}=0.4512\right)$ to the sunspot number from 1980 to 2019 .

Intense forest fires have occurred in the region of 35 degree latitudes (South Korea, California, western Russia, Australia) from the Pacific Equator during La Niña events while there were major forest fires 
in South Korea in 2019 with more expected ones in 2030 due to 11 years cyclical variation in the minimal sunspot number or the strong La Niña event. It was proposed that the maximal sunspot number induced El Niño events, GHS volcanic eruption, and Ecuadorian earthquakes, while the minimal sunspot number induced La Niña event in Ecuador, Colombia and Peru and the intensive forest fire in middle latitude countries. To decrease forest fires in California it is necessary to build rivers along the San Joaquin Valley causing air moistened while winds blow from higher pressure at the Mojave Desert passing over Sierra Nevada Mountains toward lower pressure at the Pacific Ocean. It is impossible to avoid the forest fires in Korea, Australia and California during La Niña events because of dry and warm winds before Mountains and residential land passing through bushes and trees reaching the wet and cold Sea or Ocean, where freshwater pumping is enhanced by La Niña events with stronger winds.

According to Gay-Lussac's law in physical chemistry, the temperature gradient induces the pressure gradient with winds. Bernoulli's principle in fluid dynamics states that an increase in the speed of a fluid occurs simultaneously with a decrease in static pressure. Therefore, the forest fires induced by pressure difference between hot Desert through Mountains with residential land and the cold Ocean, are vigorously activated to flare upwards. This is why it is very difficult to control the forest fires unless there is warm Sea or Ocean, instead of cold ones, for lower pressure gradient, reduced velocity gradient and flares. The area of the dry Mojave Desert can be diminished by the plants and irrigations moistening the air. The most effective solution to wildfires in Korea and California in the Northern Hemisphere is to change the events from La Niña to El Niño. Such a transition may be induced by artificial submarine volcanic eruptions among volcanoes of Fernandina, Sierra Negra and Wolf in the GHS. On the other hand Australia can be in artificial change of the events from La Niña to El Niño by using the eruptions in huge underwater volcano chain in Tasmania.

The strong damages of forest fires in South Korea, Australia and California were observed in the period of the minimal sunspot number, as were in October of 2019 to February of 2020. $\mathrm{CO}_{2}$ emissions in Australia showed $34.5 \%$ increase, $70 \%$ coal power and no nuclear power to induce bushfires because of increases of ozone hole area and UV radiation for the hot land in the period of La Niña. Fossil fuel operation should be cut down to decrease ozone hole area and UV radiation for weak bushfires in Australia. A few coming years may still have bushfires in Australia although their damages may not be as terrible as was in 2020. A simple remedy can be the reduction of $\mathrm{CO}_{2}$ emissions as low as possible.

Simultaneous transfers of momentum (velocity), heat (temperature) and mass (freshwater) were occurred from the dry zone or the hot Deserts via the Mountains and the residential land with bushes and trees to the cold Sea or Ocean.

\section{ACKNOWLEDGEMENTS}

The author expresses sincere gratitude to the University of Suwon and G-Land of South Korea for their financial supports. Editing work undertaken by Professor Jonathan Wright is also greatly appreciated.

\section{CONFLICTS OF INTEREST}

The author declares no conflicts of interest regarding the publication of this paper.

\section{REFERENCES}

1. Hathaway, D.H. (2010) The Solar Cycle. Living Reviews in Solar Physics, 7, 1. https://doi.org/10.12942/lrsp-2010-1

2. Hathaway, D.H. (2015) The Solar Cycle. Living Reviews in Solar Physics, 12, 4. https://doi.org/10.1007/lrsp-2015-4

3. https://www.weather.gov/fsd/sunspots

4. Philander, S.G. and Fedorov, A. (2003) Is El Niño Sporadic or Cyclic? Annual Review of Earth and Planetary 
Sciences, 31, 579-594. https://doi.org/10.1146/annurev.earth.31.100901.141255

5. Kim, T.J. (2018) Prevention of Avian Influenza Virus by Ultraviolet Radiation and Prediction of Outbreak by Satellite Parameters. Journal of Biomedical Science and Engineering, 11, 182-206. https://doi.org/10.4236/jbise.2018.117015

6. Kim, T.J. (2019) Predictions of El Niño, La Niña, and Record Low Chicago Temperature by Sunspot Number. Science, Natural, 11, 204-220. https://doi.org/10.4236/ns.2019.116021

7. Kim, T.J. (2019) Spanish Flu, SARS, MERS-CoV by $\mathrm{CO}_{2}$ Emission and Maximal Sunspot Number. Journal of Biomedical Science and Engineering, 12, 53-75. https://doi.org/10.4236/jbise.2019.121005

8. Null, J. (2019) Historic Oceanic Niño Index (ONI) \& La Niña Winter Impacts on United States Weather Patterns. Golden Gate Weather Patterns. https://www.ggweather.com/enso/oni_la_nina.htm

9. NOAA (2019) Equatorial Pacific Sea Surface Temperatures. https://www.ncdc.noaa.gov/teleconnections/enso/indicators/sst

10. Trathan, P.N. and Murphy, E.J. (2002) Sea Surface Temperature Anomalies near South Georia: Relationships with the Pacific El Niño Regions. Journal of Geophysical Research, 107, SOV 2-1-SOV 2-10. https://doi.org/10.1029/2000JC000299

11. Wayne (2012) The Antarctic Circumpolar Current. https://ferrebeekeeper.wordpress.com

12. MacDonald, K. (2010) What Is a Hotspot. NOAA Ocean Explorer. https://oceanexplorer.noaa.gov>hotspots

13. Glynn, P.W. (1988) El Niño-Southern Oscillation 1982-1983: Nearshore Population, Community, and Ecosystem Responses. Annual Review of Ecology and Systematics, 19, 309-346.

https://doi.org/10.1146/annurev.es.19.110188.001521

14. Fornari, D., Tivey, M., Schouten, H., Perfit, M., Yoerger, D., Bradley, A., Edwards, M., Haymon, R., Scheirer, D., Damm, K.V., Shank, T. and Soule, A. (2004) Submarine Lava Flow Emplacement at the East Pacific Rise $9^{\circ} 50^{\prime} \mathrm{N}$ : Implications for Uppermost Ocean Crust Stratigraphy and Hydrothermal Fluid Circulation. Geophysical Monography, 148, 187-218. https://doi.org/10.1029/148GM08

15. United States Geological Survey (2011) Volcano Hazards Program, 22.

16. Kim, T.J. (2018) Mitigation of Ecuadorian Earthquake Impact. Open Journal of Earthquake Research, 7, 195-219. https://doi.org/10.4236/ojer.2018.73012

17. Pidwirny, M. (2006) Earth-Sun Relationships and Insolation. Fundamentals of Physical Geography. 2nd Edition. http://www.physicalgeography.net/fundamentals/6i.html

18. Woods Hole Oceanographic (2015) Galapagos Expedition Reveals Unknown Seamounts. New Species.

19. Christy, J.R., Norris, W.B., Spencer, R.W. and Hnilo, J.J. (2007) Tropospheric Temperature Change since 1979 from Tropical Radiosonde and Satellite Measurements, Journal of Geophysical Research: Atmospheres, 112, D06102. https://doi.org/10.1029/2005JD006881

20. UAH (2019) Satellite-Based Temperature of the Global Lower Atmosphere (Version 6.0). https://www.drroyspencer.com/wp-content/uploads/UAH_LT_1979_thru_August_2019_v6.jpg

21. Smithsonian Institution (2019) National Museum of Natural History, Gloval Volcanism Program.

22. Lee, S.Y. (2010) Review of Forest Fires from 1960 to 2009. Jounal of the KoreanSociety of Hazard Mitigation, 10, 51-55.

23. Atkins, P. and Paula, J. (2010) Physical Chemistry. 9th Edition, W. H. Freeman Co., New York.

24. Balzhiser, R.E., Samuels, M.R. and Eliassen, J.D. (1972) Chemical Engineering Thermodynamics: The Study of Energy, Entropy, and Equilibrium. Prentice-Hall, Inc., Upper Saddle River.

25. Lee, D.K. and Choi, J.G. (2019) Observation of Along-Shore Current in the Northern East Sea by SARAL/AltiKa 
Sea Level Data. The Sea Journal of the Korean Society of Oceanology, 429-435.

26. Pattiaratchi, C. (2018) A Current Affair: The Movement of Ocean Waters around Australia. The Conversation, April.

27. Bray, N.A., Keyes, A. and Morawitzaratchi, W.M.L. (1999) The California Current System in the Southern California Bight and the Santa Barbara Channel. Journal of Geophysical Research, 104, 7695-7714.

https://doi.org/10.1029/1998JC900038

28. Chow, D. (2018) Huge Underwater Volcano Chain Discovered off the Coast of Tasmania.

https://www.nbcnews.com/mach/science/huge-underwater-volcano-chain-discovered-coast-tasmania-ncna92 $\underline{9881}$ 